\title{
Traumatic isolated aortic dissection
}

\author{
Ali Kemal ERENLER*, Aysun ORUÇOĞLU*, Yasemin ECE*, Mine KARABULUT*, Eşref ÇiFTÇI*
}

\section{SUMMARY}

Acute traumatic aortic injuries are rare conditions usually caused by direct or indirect forces to the abdomen induced by highenergy trauma often associated with rapid deceleration. In this report, we present an isolated traumatic aortic injury in a male patient.

A 34-year-old male patient was brought to our Emergency department because of a car accident. His only complaint was moderate chest pain. After further investigation, it was determined that the patient had aortic transection due to trauma without any concomitant injuries.

In case of suspicion from aortic injuries, patients must be investigated with contrasted Computerized Tomography, even though they do not have any concomitant injuries.

Key words: Aortic dissection, trauma, emergency department

\section{ÖZET}

\section{Travmatik izole aort diseksiyonu}

Akut travmatik aort yaralanmaları ender durumlardır ve genellikle hızlı deselerasyona bağlı olarak yüksek enerjili travma sonrası abdomen bölgesine gelen direkt ya da endirekt güçler sonucunda meydana gelir. Bu raporda sizlere erkek hastada meydana gelen izole travmatik aort yaralanmasinı sunduk.

Otuz dört yaşında erkek hasta acil servisimize araba kazası nedeniyle getirildi. Tek yakınması orta derecede göğ̈̈s ă̆rısıydı. İleri inceleme sonrasında hastada başka bir yaralanma olmaksızın aortik yırtılma saptand.

Aort yaralanması şüphesi varlı̆̆ında, eşlik eden yaralanma olmasa bile hastalar kontrastlı bilgisayarlı tomografi ile incelenmelidir.

Anahtar kelimeler: Aort diseksiyonu, travma, acil servis

\section{INTRODUCTION}

Acute traumatic aortic injuries are rare. They are normally caused by direct or indirect forces to the abdomen induced by high-energy trauma often associated with rapid deceleration ${ }^{(1)}$.

Blunt traumatic thoracic aortic injury is associated with a high mortality rate and has been implicated as the second most common cause of death in trauma patients preceded only by intracranial hemorrhage ${ }^{(2)}$.

Most patients who experience traumatic aortic dissection die at the scene of the accident before medical assistance $^{(3)}$.

In this report, we present a 34-year-old male patient admitted to our Emergency department (ED) due to in-vehicle car accident with isolated aortic thoracic dissection and aim to share our experience on this rare entity.

\section{CASE REPORT}

A 34-year-old male patient was brought to our ED due to a car accident by ambulance. On admission, the patient was alert and conscious and Glasgow Coma Scale was determined to be 15 . When the patient was questioned, he mentioned complained of back pain radiating through his chest. His vital signs on admission were as follows: systolic/diastolic blood pressure: 90/60 $\mathrm{mmHg}$, pulse rate: $140 \mathrm{bpm}$, temperature: $36.7^{\circ} \mathrm{C}$, and respiratory rate: $18 /$ minute. On initial examination, any ecchymotic lesion, tender

Geliş tarihi: 20.03 .2015

Kabul tarihi: 25.05.2015

*Hitit University Çorum Education and Research Hospital

Yazışma adresi: Yrd. Doç. Dr. Ali Kemal Erenler, Hitit Üniversitesi Çorum Eğitim ve Araştırma Hastanesi Acil Tıp Anabilim Dalı, Çorum

e-mail: akerenler@hotmail.com 
ness on any part of the body or any abnormalities related to systems were not determined. Routine blood tests were obtained and the patient underwent routine trauma X-ray imaging. Laboratory findings were found to be normal except a mild increase in white blood cell count (13190/L) and creatine kinase levels (1344 U/L). Also, any abnormalities on X-rays were not determined. During the follow-up in the observation room of the ED, the patient suffered an increasing back pain, so, a computerized tomography (CT) of chest was performed and a transection on aortic isthmus and mediastinal hematoma were determined. Also, pleural effusion on the left side was reported. For further investigation, a contrast-enhanced CT was performed and the transection of aortic isthmus was confirmed (Figure 1). The patient was consulted with cardiovascular surgeons and hospitalized for conservative follow-up. Then, the patient in our report was referred to an advance center for aortic reconstruction of aorta due to unstable health state of the patient.

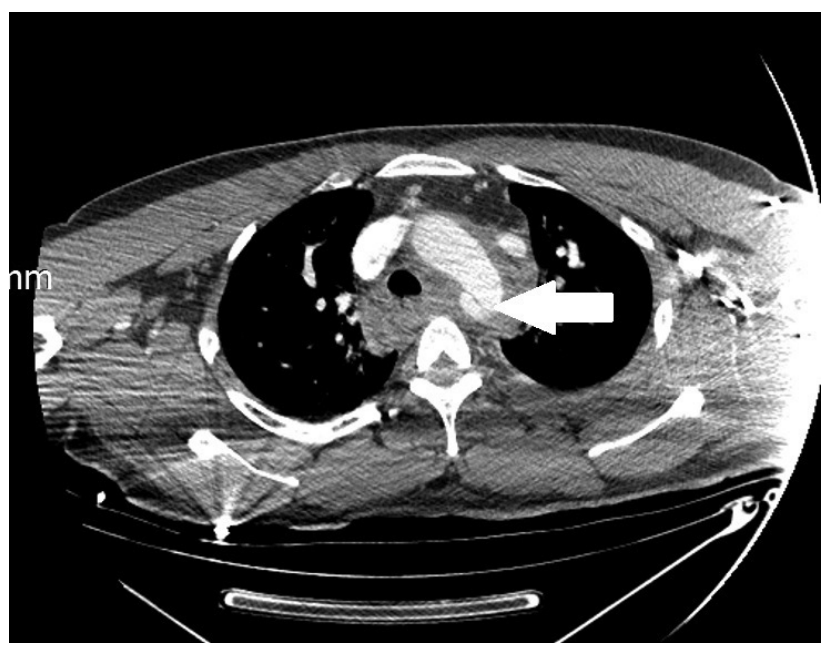

Figure 1. White arrow shows the site of transection on isthmus of aorta.

\section{DISCUSSION}

Aortic emergencies comprise different clinical entities with only one thing in common: if not diagnosed and managed in due time, they are life threatening. Compared to myocardial infarction and stroke, aortic pathologies are relatively rare. A rapid diagnosis and treatment is therefore necessary to decrease mortality ${ }^{(4)}$.
Traumatic injuries of aorta are normally caused by direct or indirect forces to the abdomen which are induced by high-energy trauma often associated with rapid deceleration ${ }^{(1)}$.

Approximately $90 \%$ of acute traumatic lesions are caused by non-penetrating car accidents ${ }^{(5)}$. In our report, the patient admitted to our ED following a car accident and a possible blunt trauma on the chest.

It is known that all cervical and thoracic cardiac rami are traced consistently to the deep cardiac plexus, which also communicates with the aorta ${ }^{(6)}$. In the thoracic region, cardiac rami arise from the T2-T6 segment of the thoracic sympathetic trunk ${ }^{(7)}$. When symptoms are investigated, chest pain and hypotension are the most common symptoms. A history of migratory pain may be helpful, but it is present in only a minority of patients with aortic dissections ${ }^{(8,9)}$. The unique complaint in our patient was radiating chest pain, compatible with the literature. Also, hypotension on admission was determined.

Our case also had a moderate but increasing chest and back pain as the sole complaint.

Because this kind of injury usually occurs due to high-energy trauma, it often accompanies by multiple life-threatening injuries ${ }^{(3)}$. However, either physical examination or imaging studies of our patient did not reveal any other concomitant injuries.

Traumatic aortic injury has to be excluded after a relevant trauma, especially when associated with hypotension, spinal, scapular, long bone or pelvic fractures, pulmonary contusion and haematothorax. CT angiography is a method of choice for diagnosing aortic injury after major trauma ${ }^{(10)}$.

Currently, the most often used imaging modality in emergency radiology is CT imaging ${ }^{(4)}$. In our case, the diagnosis was confirmed by contrasted CT.

Since the predilection site for aortic injury is at the aortic isthmus in the proximity to the left subclavian 
artery, stent graft implantation in up to $30 \%$ of the cases will result in partial or complete involvement of the left subclavian artery ${ }^{(11)}$.

In our case, a transected isthmus and a leakage through mediastinum were determined.

Since early diagnosis and management are essentials of evaluation, patients should be consulted with a vascular surgeon as soon as possible ${ }^{(3)}$.

Temporary management of initially stable patients involves using pharmacological agents to reduce the systolic blood pressure and its cardiac shear forces. However, the treatment of choice is an immediate vascular surgical reconstruction ${ }^{(12)}$.

Surgical approach to these patients involves a high posterolateral thoracotomy with or without cardiopulmonary bypass. Significant blood loss can negatively impact the pulmonary, cardiac, and neurologic status of the patient ${ }^{(2)}$.

\section{CONCLUSION}

Aortic dissection secondary to trauma is a challenging issue for both emergency physicians and cardiovascular surgeons. Early diagnosis and treatment are essential to decrease morbidity and mortality rates. In case of suspicion from aortic injuries, contrasted CT should be performed and clinicians must keep in mind that it may occur without any concomitant injuries as we presented in this case.

\section{REFERENCES}

1. Walker WA, Pate JW. Medical management of acute traumatic rupture of the aorta. Ann Thorac Surg 1990;50:965-7. http://dx.doi.org/10.1016/0003-4975(90)91131-T

2. Irace L, Laurito A, Venosi S, et al. Mid-and long term results of endovascular treatment in thoracic aorta blunt trauma. Scientific World Journal 2012;2012:396873. http://dx.doi.org/10.1100/2012/396873. Epub 2012 May 3.

3. Godry H, Rölleke G, Mumme A, et al. Traumatic Infrarenal Aortic Dissection After a High-energy Trauma: A Case Report of a Primary Missed Diagnosis. Orthop Rev (Pavia) 2014;6:5031.

http://dx.doi.org/10.4081/or.2014.5031. eCollection 2014.

4. Voitle E, Hofmann W, Cejna M. Aortic emergencies-diagnosis and treatment: a pictorial review. Insights Imaging 2015;6:17-32. http://dx.doi.org/10.1007/s13244-014-0380-y. Epub 2015 Feb 1.

5. Fleming AW, Green DC. Traumatic aneurysms of the thoracic aorta. Report of 43 patients. Ann Thorac Surg 1974;18:91-101. http://dx.doi.org/10.1016/S0003-4975(10)65722-0

6. Pather N, Partab P, Singh B, et al. The sympathetic contributions to the cardiacplexus. Surg Radiol Anat 2003;25:210-5. http://dx.doi.org/10.1007/s00276-003-0113-2

7. Ueno M, Omori K, Yanagawa Y. A case of Stanford B type aortic dissection in a patient whose initial complaints were a toothache and leftshoulder pain. J Emerg Trauma Shock 2015;8:69-70. http://dx.doi.org/10.4103/0974-2700.150404

8. Hagan $\mathbf{P}$, Nienaber $\mathbf{C}$, Isselbacher $\mathbf{E}$, et al. The international registry of acute aortic dissection (IRAD): new insights into an old disease. JAMA 2000;283:897-903. http://dx.doi.org/10.1001/jama.283.7.897

9. Desai SC, Chute DJ, Desai BC, et al. Traumatic dissection and rupture of the abdominal aorta as a complication of the Heimlich maneuver. J Vasc Surg 2008;48(5):1325-7. http://dx.doi.org/10.1016/j.jvs.2008.05.061

10. Authors/Task Force M, Erbel R, Aboyans V, et al. 2014 ESC guidelines on the diagnosis and treatment of aortic diseases: document covering acute and chronic aortic diseases of the thoracic and abdominal aorta of the adult. The task force for the diagnosis and treatment of aortic diseases of the European Society of Cardiology (ESC). Eur Heart J 2014;35(41):2873-2926. http://dx.doi.org/10.1093/eurheartj/ehu281

11. Lee WA, Matsumura JS, Mitchell RS, et al. Endovascular repair of traumatic thoracic aortic injury: clinical practice guidelines of the Society for Vascular Surgery. J Vasc Surg 2011;53:187-192. http://dx.doi.org/10.1016/j.jvs.2010.08.027

12. White A, Broder J. Acute aortic emergencies-part 1: aortic aneurysms. Adv Emerg Nurs J 2012;34:216-29. http://dx.doi.org/10.1097/TME.0b013e31826133b0 